\title{
Proverbs 30:18-19 in the Light of Ancient Mesopotamian Cuneiform Texts
}

\author{
Barbara Böck * \\ ILC - CSIC, Madrid
}

The meaning of Proverbs 30:18-19 has long been disputed. Most scholars interpret the Biblical couplets textually on stylistic features only; an explanation of the contextual association between the four motifs mentioned (eagle, serpent, boat, man and woman) has not yet been undertaken. The present paper aims at shedding light on the motivation for this association, taking into consideration ancient Near Eastern cuneiform compositions for the first time. It is further suggested that Proverbs 30:18-19 derived originally from a riddle that had its setting in a wedding ceremony.

Keywords: Biblical Proverbs; Metaphors of Procreation; Ancient Near Eastern Background; Riddles.

PRoverbios 30:18-19 A LA LUZ DE LOS ANTIGUOS TEXTOS MESOPOTÁMICOS CUNEIFORMES.El significado de Proverbios 30:18-19 sigue desafiando la exégesis de los biblistas. La mayoría de los comentaristas interpretan los versos bíblicos textualmente, ciñéndose al análisis de las figuras de estilo. Sin embargo, todavía no se ha dado ninguna explicación a la asociación contextual entre los cuatro motivos del proverbio (águila, serpiente, barco, hombre y mujer). Por primera vez, este artículo estudia composiciones de la literatura cuneiforme que ofrecen un telón de fondo para interpretar el sentido de los distintos elementos y del conjunto del proverbio bíblico. Según esta nueva lectura, Proverbios 30:18-19 describiría una adivinanza propuesta durante una ceremonia matrimonial.

Palabras Clave: Proverbios bíblicos; metáforas de procreación; antigua Mesopotamia; adivinanzas.

More than a century of research has provided a scattering of potential borrowings from Ancient Mesopotamia into Israelite literature. Studies of origin and diffusion of foreign ideas, themes and motifs that entered remodeled into ancient Israelite thought have been undertaken; and channels and routes of tradition bearers have been mapped. As for wisdom literature, both Biblical scholars

\footnotetext{
*barbara.boeck@cchs.csic.es
} 
and Assyriologists have constantly stressed the common background of Mesopotamian and Israelite cultures.

This paper does not attempt to contribute to the long discussion about the precise authorship and milieu of the Israelite Book of Wisdom as compared to Ancient Mesopotamian literature, nor to the debate whether Proverbs is primarily a scribal work originating from/in the royal court or whether it is rooted in the folk culture of tribal and family life. ${ }^{2}$ Our aim is to discuss one of the sayings collected in chapter 30 of the Hebrew wisdom book and to propose an explanation for associating four motifs which appear in the couplets in question in the light of Ancient Mesopotamian literature. We also venture to suggest a likely setting of Proverbs 30:18-19, a context the Hebrew text does not provide because of its nature. As it is well known, the Book of Proverbs is composed of a series of collections and independent discourses, each one with its own history of origin. Some of the verses are grouped together according to a common structure while others are brought together because of the similar ideas, themes or subjects they express. It is apparent from this inner organization that any information for the study of the context or the proverb performance and its function in relation to its hearer has got lost.

\section{The Biblical Proverb 30:18-19}

"There be three things which are too wonderful for me, yeah, four which I know not:

The way of an eagle in the air; the way of a serpent upon a rock; the way of a ship in the midst of the sea; and the way of a man with a maid." ${ }^{4}$

${ }^{1}$ Abbreviations of the assyriological literature follow W. vON Soden, Akkadisches Handwörterbuch III (Wiesbaden 1981), pp. ix-xvi. It would be beyond the scope of this paper to list all studies on Ancient Near Eastern wisdom literature which have appeared in the last years; see e.g. the contributions in R. J. CLIFFORD (ed.), Wisdom Literature in Mesopotamia and Israel (Atlanta, GA 2007) and in L. G. Perdue (ed.), Scribes, Sages, and Seers. The Sage in the Eastern Mediterranean World (Göttingen 2008).

${ }^{2}$ See e.g. the contributions of F. W. Golka, Biblical and African Wisdom in Proverbs (Edinburgh 1993); C. Westermann, Roots of Wisdom: The Oldest Proverbs of Israel and Other Peoples (Louisville, KY 1995); L. G. Perdue, Wisdom Literature: A Theological History (Louisville, KY 2007); for the discussion of literacy and the role of schools in the recompilation of the Hebrew Bible, see K. van der Toorn, Scribal Culture and the Making of the Hebrew Bible (Cambridge, MA - London 2007).

${ }^{3}$ See for the problem of contextualising proverbs C. R. FonTAINE, "Proverb Performance in the Hebrew Bible," JSOT 32 (1985), pp. 87-103.

${ }^{4}$ Translation after King James Version. 
Proverbs 30:18-19 is part of the section chapter 30:15-33, which -because of stylistic affinities- forms a literary unit as it is generally assumed. ${ }^{5}$ The saying belongs to those proverbs which employ a graded numerical sequence as poetic device. ${ }^{6}$ The meaning of the proverb has been much debated; whereas the Hebrew term "way" (dere $\underline{k}$ ) links clearly as a stylistic feature the motifs of eagle, serpent, ship, and man and woman, as stressed by all commentators, only few contextual interpretations have shed light on a possible motivation for associating these four elements. One of the main obstacles of the interpretation consists in the sequence of the animals, the ship and the man, which is not otherwise attested in the Bible. Emphasis has been laid, therefore, on passages in which at least two of the four motifs appear together, such as Wisdom of Solomon 5:10-11, which refers to the passing by of a boat and the flight of a bird and Job 9:15-16, in which the passing days are also compared to a reed-boat and an eagle swooping on its prey. However, both passages and the images used have a somewhat pessimistic tone which does not fit into the tenor of Proverbs 30:1819. Various scholars stress the inexplicability of motion, which appears to the author of the proverb as wondrous; others understand the lines as a lesson in natural history and a picture of the world referring to the elements of air, earth, and water and to human procreation. In either case, as already mentioned, the connection with the human situation is difficult to explain.

\section{THE INTERPRETATIONS IN DETAIL}

In what follows, we give an overview of the different readings of Proverbs 30:18-19. C. H. Toy observes that what seems to be common to the phenomena at first sight is the aspect of their tracelessness. According to him, this characteristic cannot be taken as an explanation of the fourth instance, so the passage rather deals with examples that would "excite the admiration of the writer." The observation of movement and human procreation is, according to him, "a lesson

${ }^{5}$ It seems that only G. SAUER in his Die Sprüche Agurs. Untersuchungen zur Herkunft, Verbreitung und Bedeutung einer biblischen Stilform unter besonderer Berücksichtigung von Proverbia c. 30 (Stuttgart 1963) defends the idea that the whole chapter 30 would belong to the sayings of Agur. An overview and discussion of the different divisions of the chapter can be found in R. N. WhyBray's study The Book of Proverbs: A Survey of Modern Study (Leiden - New York - Köln 1995), pp. 86-91; see also W. McKane, Proverbs. A New Approach (London 1970), pp. 643-647; and A. E. Steinmann, "Three Things ... Four Things ... Seven Things. The Coherence of Proverbs 30:11-33 and the Unity of Proverbs 30," Hebrew Studies 42 (2001), pp. 59-66.

${ }^{6}$ See the classic study of M. W. Rotн, "The Numerical Sequence X/X+1 in the Old Testament," VT 12 (1962), pp. 301-307 and his Numerical Sayings in the Old Testament (Leiden 1965). 
in natural history and physics." ${ }^{7}$ C. F. Keil and F. Delitzsch interpret the first three comparisons as similes for movements that leave no track. Since the way of a man with a maid would manifest itself as pregnancy, the connection of the former three with the fourth cannot be sought in metaphors for incomprehensible ways. "The point of comparison hence is not the secret of conception, but the tracelessness of the carnal intercourse." ${ }^{8}$ The ancients, as W. O. E. Oesterley states, express in these lines amazement about the different kinds of movement which, because of lack of scientific knowledge, escape explanation: the heavy vulture which does not fall to the ground, a serpent which crawls without feet or legs, a heavy boat which does not sink, and the procreation of a human being. ${ }^{9}$ E. F. Sutcliffe adds a rather Christian allegorical interpretation referring to Jesus Christ first formulated in the $13^{\text {th }}$ century by the Dominican cardinal Hugh of St-Cher. ${ }^{10}$ R. B. Y. Scott gives a summary of previous opinions, pointing out that especially the application of the former parables to the human situation is a problem. In addition to the idea that there is a reference to the mystery of procreation, Scott puts forward that "there are also the attendant mysteries of the attraction of the sexes in general, and of love of a particular man for a particular woman." ${ }^{11} \mathrm{~W}$. McKane suggests that the proverb refers to the mystery and wonder of the movement of an eagle or a serpent, which serve as "parables of the mystery of a man's desire for a woman." ${ }^{12}$ Also O. Plöger agrees that the saying offers a list of wondrous items of daily life; common to all items is the observation that they do not leave any traces in their movement.$^{13}$ A. Meinhold comments that the movements in heaven, earth and sea cause admiration since they are beyond human comprehension. Whereas the eagle, the serpent and the boat are truly forms of movement, the encounter between a man and a woman is rather allegorical. ${ }^{14} \mathrm{R}$. N. Whybray explains the proverb as a list of phenomena of mysterious manners of motion, which constitute a climax from the animal to the human world. He proposes that the numerical proverb refers to "human

${ }^{7}$ A Critical and Exegetical Commentary of the Book of Proverbs (Edinburgh 1899), pp. 530-531 (quote from p. 531).

${ }^{8}$ Proverbs, Ecclesiates, Song of Solomon. Commentary on the Old Testament in Ten Volumes (Grand Rapids, MI 1950), p. 297.

${ }^{9}$ The Book of Proverbs (London 1929), pp. 276-277.

10 “The Meaning of Proverbs 30:18-20," Irish Theological Quarterly 27 (1960), pp. 125-131.

${ }^{11}$ Proverbs, Ecclesiates. The Anchor Bible (New York 1965), p. 181

${ }^{12}$ Proverbs. A New Approach (London 1970), pp. 657-658 (quote from p. 658).

${ }^{13}$ Sprüche Salomos (Proverbia) (Neukirchen 1984), pp. 363-364.

${ }^{14}$ Die Sprüche. Teil 2: Sprüche Kapitel 16-31 (Zürich 1991), pp. 508-509. 
gestation and birth - the formation of a child in the womb, which is equally seen as a great mystery." 15 P. J. Nel suggests that the four observations in the proverb stand for the categories of air, earth, water and the spiritual. Within these categories, there are four ways of motion described that deserve admiration since they cannot be explained. ${ }^{16}$ R. E. Murphy and E. Huwiler, in their commentary, emphasize the mystery that lies behind the different ways including the "relationship between sexes, there is the mysterious attraction behind the way." "Also T. L. Forti stresses the motif of wonder which the movements of the eagle, the serpent and the boat share with the relation between man and woman or "the mystery of a woman's attraction to a man." "In her discussion of the animal imagery of Proverbs 30:18-19, Forti -in contrast to the aforementioned commentators- includes also the following verse 20 as belonging to the Proverb. Since this line is not readily relevant for this discussion, it has not been taken into account.

\section{An Ancient Mesopotamian Background}

As it has become evident from the previous collection of opinions, the interpretation of the proverb contents -namely, the raison d'être for choosing an eagle, a serpent, a boat, and a man and a woman- has been explained literally as referring to living beings and items that leave no trace of moving in their respective realms of heaven, earth, and sea. In Ancient Mesopotamian folklore and literature, we do find contextual associations between the eagle and the serpent, on the one hand, and the serpent and the boat on the other. This could shed light on the background for being cited together in Proverbs 30:18-19. In addition, according to Mesopotamian tradition, all three elements are related to conception, birth and procreation, which would perfectly agree with the interpretation of the majority of Biblical commentators on the meaning of the last couplet of Proverb 30:19 as referring to love and gestation.

The themes of procreation, the flying eagle, and the association of the eagle and the serpent are well-known narrative elements in the Akkadian tale of

${ }^{15}$ Proverbs, New Century Bible Commentary (Grand Rapids, MI 1994), pp. 415-416 (quote from p. 416).

16 “Juxtaposition and Logic in the Wisdom Saying," JNSL 24 (1998), pp. 115-127: 124.

${ }^{17}$ Proverbs, Ecclesiastes, Song of Songs. New International Biblical Commentary (Peabody, Mass. 1999), p. 149.

${ }^{18}$ Animal Imagery in the Book of Proverbs (Leiden - Boston 2008), p. 127. 
Etana. Episodes of the eagle and the serpent are also common to another cuneiform narrative, the Sumerian story of Gilgameš, Enkidu and the Netherworld. Moreover, the combination of the eagle and the serpent has a long iconographic tradition as it is evident from cylinder seals dating from the Uruk and Djemdet Nasr periods (from the middle of the $4^{\text {th }}$ millennium to the beginning of the $3^{\text {rd }}$ millennium BCE). ${ }^{19}$ The slithering serpent, on the other hand, appears to be a metaphor of the baby about to be delivered in several cuneiform birth incantation texts and, as it is well known, it is associated with the "plant of life / birth / youth" in the Gilgameš Epic. As with to the serpent, we also find the image of the boat in the corpus of these birth incantations used to describe the situation of a woman in labor. The three themes shall be discussed more in detail .

\section{THE MOTIF OF THE EAGLE'S FLIGHT}

The episode of the flight of the eagle is incorporated into the tale of the legendary king of Kiš, the Etana Epic, which belongs to the oldest Semitic epic narratives. ${ }^{20}$ The versions preserved date from the Old-Babylonian, Middle- and Neo-Assyrian period (roughly from 1900-700 BCE). ${ }^{21}$ Etana is described according to the Sumerian King List as "the shepherd who ascended to heaven, consolidated all the countries (and) became king." ${ }^{22}$ As far as the extant manuscripts of the narrative are preserved, we learn that Etana's wife is barren and sees in a dream the "plant of birth." Etana consequently sets off in search for this plant. There are two episodes intertwined in the protagonist's search, one of the eagle and the serpent living together, and another one, of the eagle carrying Etana on her wings to heaven. As for the first episode, both animals had agreed a pact on living and hunting together. Their friendly gregariousness comes to a bad end when the eagle one day devours

${ }^{19}$ See for the last treatment with further literature E. Rova, "The Eagle and the Snake. Remarks on the Iconography of Some Archaic Seals," Kaskal 3 (2006), pp. 1-29.

${ }^{20}$ See G. Selz, "Die Etana-Erzählung. Ursprung und Tradition eines der ältesten epischen Texte in einer semitischen Sprache," Acta Sumerologica 20 (1998), pp. 135-179.

${ }^{21}$ The most recent edition is owed to M. Haul, Das Etana-Epos. Ein Mythos von der Himmelfahrt des Königs von Kiš (= Göttinger Arbeitshefte zur altorientalischen Literatur 1) (Göttingen 2000). For a convenient overview of the textual history, see also the table provided by B. Alster, "The Textual History of the Legend of Etana," JAOS 109 (1989), pp. 81-86: 82.

${ }^{22}$ See for the edition of the text Th. JACOBSEn, The Sumerian King List, Assyriological Studies 11 (Chicago 1939), and for further discussion C. WILCKE, "Die sumerische Königsliste und erzählte Vergangenheit," in J. von Ungern-Sternberg \& H. Reinau (eds.), Colloquium Rauricum. Vol. 1: Vergangenheit in mündlicher Überlieferung (Stuttgart 1988), pp. 113-140. 
the serpent's children and breaks thus the oath both animals had formerly sworn. The serpent appeals to the sun god Šamaš for help and takes its revenge. Hidden in the carcass of an ox, the serpent waits for the eagle, which promptly comes off from the sky to catch her prey. Next we see the serpent pulling out the eagle's feathers and throwing her into a deep pitch. Now, the eagle prays to Šamaš for help; in response the sun god directs Etana's steps to the pitch to rescue the animal. Etana, then, feeds and takes care of the eagle until she grows new feathers. As a reward, the eagle takes him on her wings to heaven where he would find the "plant of birth." But the eagle returns at least twice unsuccessfully, during the flights he drops and catches again Etana three times. At this point of the story the tablet breaks off so that the end remains unknown. In view of the narrations about the legendary king of Uruk, Gilgameš, who sets out to seek the "plant of youth" but does not get hold of it, it is quite likely that neither did Etana obtain the "plant of birth." ${ }^{23}$ Nevertheless, according to the tradition of the Sumerian King List, his journey must have been successful since it reports a son of his, Balik, named after the homonymous river which originates in Turkey and empties in Syria into the Euphrates.

The motive of Etana's flight on the eagle became widespread as it is well known: ${ }^{24}$ it entered not only classical literature like Aelian's De natura animalium or the Alexander Romance, but also modern literature of Kurdistan, Syria, and Uzbekistan. ${ }^{25}$ Remarkable is the parallel to a Finnish tale as described by M. Haavio, which preserves almost all motifs of Etana. ${ }^{26}$ Little attention, however, has been paid to the theme of "Young man carried off by an eagle" in Jewish tradition; ${ }^{27}$ According to the extant folktales, an eagle carries on her wings a young hero to his destined bride. ${ }^{28}$ Most inspiring for an interpretation

${ }^{23}$ See for skeptical remarks about a "happy end" of the Etana's tale, Haul, Das Etana-Epos, p. 32; and W. F. M. Henkelman, "The Birth of Gilgameš (Ael. NA XII.21). A Case-Study in literary Receptivity, " in R. Rollinger \&- B. TruschnegG (eds.), Altertum und Mittelmeerraum: Die antike Welt diesseits und jenseits der Levante. Festschrift für Peter W. Haider zum 60. Geburtstag (Stuttgart 2006), pp. 807-853: 841; different, however, Selz who favors/favours (UK) a positive result of Etana's search because of the inner coherence of the tale, "Die EtanaErzählung. Ursprung und Tradition,” pp. 145-146.

${ }^{24}$ See I. Levin, "Etana. Die keilschriftlichen Belege einer Erzählung, ” Fabula 8 (1966), pp. 1-63; and Henkelman, "The Birth of Gilgameš," pp. 807-853.

${ }^{25}$ See J. Aro, "Anzu and Sīmurgh," in B. Eichler (ed.), Kramer Anniversary Volume (= AOAT 25) (Kevelear 1976), pp. 25-28.

${ }^{26}$ See M. HaAvio, Der Etanamythos in Finnland (Helsinki 1956).

${ }^{27}$ But see Henkelmann, “The Birth of Gilgameš,” p. 840.

${ }^{28}$ See Ben-Amos, D. Noy \& E. Frankel, Folktales of the Jews. Vol. I: Tales from the Sephardic Dispersion (Philadelphia, PA 2006), pp. 373-374. 
of Proverbs 30:18-19 is perhaps Ch. N. Bialik's novel “The Legend of Three Things and Four" ${ }^{29}$ for which he relied on a passage from the Midraš Tanḥuma commenting on the proverb. The story tells of a young man who is dropped on the rooftop of a tower in which a young maiden is locked up. After having fallen in love to each other, they both agree on marriage. ${ }^{30}$

The connection between birth and the eagle can be likewise found in a classical context in the so-called eagle-stone (aitites). In his study Birth in Babylonia and the Bible. Its Mediterraenean Setting, M. Stol drew attention to the works of Theoprastus, Dioscurides, and Pliny who attribute to the stone the power of preventing miscarriage and facilitating birth. The eagle-stone is described as hollow and enclosing another smaller stone which rattles. ${ }^{31}$ Cuneiform medical texts do not hint to the existence of such a stone, but as it has been suggested, a word pun of homonyms, namely the Akkadian verb erû $(m)$ 'to be pregnant' and the Akkadian term for eagle $\operatorname{eru}(m)$ might reflect the notion of this connection. ${ }^{32}$

\section{THE MOTIF OF THE SLITHERING SERPENT}

The role and symbolism of the serpent and its manifold manifestation in mythology have been thoroughly discussed. ${ }^{33}$ One of the symbolic functions refers to the serpent as a life-giving animal by emphasizing the aspect of skinning as a sign of its apparent rejuvenation, a motif that is first attested in the Babylonian Epic of Gilgameš. ${ }^{34}$ Of far more relevance for the present discussion is the association of birth and the snake, as evidenced by a number of Akkadian incantations. Most of these spells that accompany the treatment of women in birth pangs can be found in the cuneiform tablet VAT 8869 which has been published in autograph by F. Köcher as BAM III 248. The text was unearthed in the ancient

${ }^{29}$ See Random Harvest: The Novellas of Bialik, (translated by D. PATTERSON \& E. SPICEHANDLER) (Boulder, CO 1999), pp. 227-286. For the importance of Bialik's works, see G. SHAKED, "Modern Midrash: The Biblical Canon and Modern Literature," ASJ Review 28 (2004), pp. 43-62: 51-55.

${ }^{30}$ See the commentary of Ben-Amos, Folktales of the Jews, vol. I, p. 375.

${ }^{31}$ Groningen 2000 , pp. 50-51 (with further references).

32 See R. C. Thompson, A Dictionary of Assyrian Chemistry and Geology (Oxford 1936), p. 105 , and E. ReIner, Astral Magic in Babylonia (Philadelphia, PA 1995), pp. 123-124. One might drive the homonymous wordplay even further referring to the Sumerian terms for 'eagle' ti ${ }_{8}$ and ti, 'life.'

${ }^{33}$ See e.g. H. EgLi, Das Schlangensymbol. Geschichte, Märchen, Mythos (Olten - Freiburg i. Br. 1982); P. KüBEL, Metamorphosen der Paradieserzählung (Fribourg - Göttingen 2007).

${ }^{34}$ See for a discussion A.R. George, The Babylonian Epic of Gilgamesh. Introduction, Critical Edition and Cuneiform Texts (Oxford 2003), vol. I, pp. 524-526. 
city of Assur and dates from the $8^{\text {th }}-7^{\text {th }}$ centuries BCE. ${ }^{35}$ This is one of the few preserved cuneiform compendia which include a variety of healing recommendations and incantations recited for relieving birth pangs. ${ }^{36}$ The image of the baby about to be delivered as a slithering serpent or gliding little snake appears in four of the eleven incantations written on the cuneiform tablet. ${ }^{37}$ In two of the incantations, the snake simile closes the magical spell:

$B A M$ III 248 i:49 and BAM III 248 i:60:

"Like a snake glide out, like a little serpent may it slip out!" ${ }^{38}$

BAM III 248 iii: $36-45^{39}$ :

"Incantation: Narundi, Nabundi ${ }^{40}$ - nanamgišer.

There was a cow of the moon god Sîn, Geme-Sîn ('maid of Sîn') was her name.

At her wailing and her cries in birth pangs

The shining moon god Sîn heard her screaming.

'Who (if not) Narundi, who (if not) Nahundi (can help)?

This cow, $\mathrm{O}$ lord, is having great difficulty in giving birth,

O lord, pour water from your water bucket on her, so that

The cow Geme-Sîn may open her front,

So that (the offspring) may come out like a snake and slip out like a small serpent,

May it fall down like dust from the wall!' She shall not turn her back! Wording of the incantation."

${ }^{35}$ The material is older as shown by the Middle-Babylonian text published as KUB IV 131. 15-22, see N. Veldhuis, A Cow of Sin (Groningen 1991), p. 65.

${ }^{36}$ The only complete translation is E. EBELING, "Keilschrifttexte medizinischen Inhalts. IV," Archiv für Geschichte der Medizin 14 (1923), pp. 65-78 which is outdated. Structure, further text duplicates, and several aspects of the text have been discussed by N. VeldHUIS, "The New Assyrian Compendium for a Woman in Childbirth," Acta Sumerologica 11 (1989), pp. 239-260, and STOL, Birth in Babylonia and the Bible, pp. 64-72. One of the incantations of the tablet has been treated, separately; see VeldhuIs, A Cow of Sin.

${ }^{37}$ In BAM III 248 iii: 44 we read liṣ̂a kìma șerri kīma nirāhi liššalila 'May you come forth like a snake, like a little snake may you slip out!'; in BAM III 248 iv:2 nerruba kīma nirāhi 'Flee towards me little snake!'

${ }^{38}$ The Akkadian reads kīma șerri nešelpâ kīma nirāhi [liš $]$ ša[lila] (restored after BAM III 248 iii:44). The passage in BAM III 248 i:50 mentions still a third snake but the name is broken off.

${ }^{39}$ The passage has been translated several times; see e.g. STOL, Birth in Babylonia and the Bible, p. 68 with further references.

${ }^{40}$ The two names refer to Elamite goddesses. According to the cuneiform commentary text $11 \mathrm{~N}-\mathrm{T} 3$, Narundi and Nahundi are equated with sun and moon; see M. CIvIL, "Medical Commentaries from Nippur," JNES 33 (1974), pp. 329-338: 332, 1. 27 and p. 334. 
BAM III 248 col. iv:2-3 ${ }^{41}$ :

"Incantation: Run away like a gazelle, slip out like a little serpent!

I am Asalluhhi, the midwife - I will receive you! Wording of the incantation."

The snake and gazelle association seems to be a well-known motif in Ancient Mesopotamian literature. Interestingly, it is also employed in the Sumerian stories about Dumuzi's Dream and Inanna's Descent to the Netherworld. In both narratives, young Dumuzi runs away from the demons that intend to catch him and bring him to the nether world where he is condemned to spend six months each year. He succeeds twice in escaping his persecutors by changing his figure. After having appealed to the sun god Utu, he is first given hands or feet of a gazelle, and then, for the second getaway, hands or feet of a snake. ${ }^{42}$ The appearance of the snake in this context stresses the function of the metaphor as an image of a quick exit or escape.

\section{ThE MOTIF OF THE BOAT AMIDST THE SEA}

Among the imagery used in cuneiform birth incantations, two typical motifs appear, one referring to the baby as a boat and the other one referring to the sea as amniotic water. ${ }^{43}$ As for the latter, an Old Babylonian text describes how the fetus is moving over the far-off waters of the sea. The passage in question reads as follows ${ }^{44}$ :

${ }^{41}$ Also B. R. Foster offers a translation of this incantation, see Before the Muses $\left(3^{\text {rd }}\right.$ ed. Bethesda, Md 2005), p. 1008.

${ }^{42}$ According to Inanna's Descent to the Netherworld young Dumuzi is given hands and feet of a snake. In lines 373-375 Dumuzi pleads the sun god Utu: "Turn my hands into snake's hands! Turn my feet into snake's feet, so that I can escape the demons (that are) after me!" Dumuzi's appeal is accepted by Utu and stated affirmatively in lines 377-378 of the text. For the narrative in transliteration and translation see the webpage etcsl.orinst.ox.ac.uk, sections c.1.4.1 and t.1.4.1; see also W. R. SLADEK, Inanna's Descent to the Netherworld (PhD thesis, University Microfilms, Ann Arbor, MI 1974). See for Dumuzi's Dream the webpage etcsl.orinst.ox.ac.uk with the sections c.1.4.3 and t.1.4.3; for hands and feet of the gazelle see lines 176-177 "Please, change my hands into the hands of a gazelle! Change my feet into the feet of a gazelle!" and for the snake which is only attested in one manuscript see lines 197-198, 202-202, and 236-237. See for the standard edition B. Alster, Dumuzi's Dream. Aspects of Oral Poetry in a Sumerian Myth (Copenhagen 1972), and see his “New Sources for Dumuzi’s Dream,” ZA 96 (2006), pp. 1-30.

${ }^{43}$ For the symbolism of the baby and the sea see already J. J. A. van DiJK, "Incantations accompagnant la naissance de l'homme," OrNS 44 (1975), pp. 52-79: 73-74; for the baby as a boat see pp. 74-75. On the boat motif see also the discussion of SтоL, Birth in Babylonia and the Bible, pp. 62-63.

${ }^{44}$ The tablet in question is YBC 4603 (= YOS XI 86) which has been first published by J. J. A. 
In the waters of intercourse, the bone was formed;

In the flesh of muscles, the baby was created.

In the ocean waters, fearsome, raging,

In the far-off waters of the sea

Where the little one is - his arms are bound!

The connection between the unborn baby, the waters of the amniotic fluids -expressed in Akkadian with the term tiamtu(m) " "sea ocean"”-, and a boat is explicitly stated in a whole set of Sumerian, Sumero-Akkadian bilingual, and Akkadian incantations and appears as a typical motif. ${ }^{45}$ One of these Sumerian texts describes the mythological picture of the unborn child as a boat that the goddesses Inanna and Ninhursaga steer through the amniotic waters. The boat is loaded with perfume, cedar wood and precious stones, namely cornelian or lapis lazuli that refers to the gender of the baby. Next appears Asalluhi, son of the allwise god of magic Enki, who seeks his father's advice to help the woman, then the text breaks off. According to its rubric, the incantation is meant for a woman having difficult labor. The text reads as follows ${ }^{46}$ :

The woman who was about to give birth steered the reed boat through the water,

Pure Inanna steered the reed boat through the water,

Ninhursaga steered the reed boat through the water.

As if it would be a boat carrying perfume, perfume has been loaded,

As if it would be a boat carrying cedar wood, cedar wood has been loaded,

As if it would be a boat for cornelian or lapis lazuli, she loaded cornelian or lapis lazuli.

The woman ...

Asalluhi saw her,

And to his father Enki he entered the house.

Another text offers the following description:

van Disk, "Une variante du thème de 'l'Esclave de la Lune'," OrNS 41 (1972), pp. 339-348; see also STоL, Birth in Babylonia and the Bible, pp. 10-11.

${ }^{45}$ See e.g. the texts VS 17 34; YOS XI 86; VS 17 33; UM 29-15-367 (see for the publication van DıJ, "Incantations accompagnant la naissance de l'homme," pp. 52-79); AUAM 73.3094 (see for the publication M. E. COHEN, "Literary Texts from the Andrews University Archeological Museum," RA 70 [1976], pp. 129-144); E 47.190 (see for publication G. FARBER, "Another Old Babylonian Childbirth Incantation," JNES 43 [1984], pp. 311-316). For more birth-related incantations see G. Cunningham, 'Deliver Me from Evil'. Mesopotamian Incantations 2500-1500 $B C$ (Rome 1997), pp. 107-108.

${ }^{46}$ The text is E 47.190 lines 1-9 for which see FARBER, “Another Old Babylonian Childbirth Incantation," pp. 313-314. 
As if she [= the woman in labor] were the boat of the En priest, she hoists the sails;

As if she were the royal barge, she ships merchandise;

As if she were the vessel 'It is humankind', she is loaded with cornelian or lapis lazuli.

The boat metaphor also appears in a number of first millennium Akkadian birth incantations. As the woman is in difficult labour, emphasis is laid here on the safe departure and arrival of the child-boat. Again, the cuneiform tablet VAT 8869 (BAM III 248) should be quoted ${ }^{48}$ :

May the ship (arrive) well in the ...

May the barge (arrive) felicitously in the ...

May her taut mooring rope be slackened,

And her closed door be opened,

The mooring rope of the boat for the quay of well-being,

The mooring rope of the barge for the quay of health.

Another incantation of the compendium offers the following description:

At the quay of death the ship is kept,

At the quay of distress the barge is kept,

From the sun god Utu, lord of judgment,

Speak to the goddess Belet-ili, [midwife?] of the womb:

'May the way be straightened, may (the baby) come forth from the darkness and see the day light!' ${ }^{9}$

The metaphor of the pregnant woman as a boat was not only restricted to the genre of birth incantations but entered other literature, such as the divinatory texts on extispicy. This confirms that the image was rather common. In an apodosis in one of the numerous liver omens, we find the following prediction: "The fully loaded boat will sink or the pregnant woman will die in her giving birth." ${ }^{50}$

${ }^{47}$ The text is UM 29-15-367 lines 12-14 for which see van DiJK, "Incantations accompagnant la naissance de l'homme," p. 55.

${ }^{48}$ Col. II lines 47-52; see also StoL, Birth in Babylonia and the Bible, p. 65.

${ }^{49}$ Col. I lines 62-66.

${ }^{50}$ StOL, Birth in Babylonia and the Bible, p. 62 refers to U. JEYEs, Old Babylonian Extispicy. Omen Texts in the British Museum (Istanbul 1989), p. 97 text no. 1 line 6. 


\section{ON EAGLE, SERPENT, AND BOAT IN CUNEIFORM LITERATURE AND PROVERBS 30:18-19}

As it is evident from the examples given for the themes of the eagle, the serpent and the boat, there is no cuneiform text that would incorporate all three elements in one text. The combination of the three seems to be an innovation by the author of the Hebrew proverb. In the light of the tale of Etana, we can explain the eagle in the sky as a means of transport in order to obtain the miraculous "plant of birth", and thus interpret the "way of the eagle" in Proverbs 30:18, with procreation echoing from the distance this ancient Mesopotamian motif. As it has been stated above, the co-existence of the eagle and the serpent, which would be the source of inspiration for associating the eagle and the serpent in this proverb, is a well-known motif in Ancient Mesopotamian literature, art, and religion. In the tale of Etana, both animals seem first to peacefully inhabit the Euphrates poplar until their partnership breaks off.

The closest parallel to the co-existence of the eagle and the snake is found in the Sumerian narrative of Gilgameš, Enkidu and the Nether World. Both animals share the same dwelling place with the female demon Kisikillilla, namely the so-called halub-tree, ${ }^{51}$ which has been planted for the goddess of love and war, Inanna. Now, Kisikillilla belongs -together with Ardat-lilî- to those evil female spirits who cannot conceive or bear any children and whose milk is like poison when they wet-nurse a baby. ${ }^{52}$ Therefore, they represent just the opposite element of procreation and birth. It should be noted that the thought-motif of the halub or haluppu-tree in association with birth is also shared by the ancient Mesopotamian lore of medicinal plants. Among the list of healing plants employed as simple drugs for the treatment of a woman who does not become pregnant, the seed of the haluppu-tree is recommended. ${ }^{53}$ In all likelihood, we should

${ }^{51}$ It is uncertain to what tree this term refers; suggestions range from oak to poplar and willow, see for a discussion which favors/favours the meaning willow J. KEETMAN, "König Gilgameš reitet auf seinen Untertanen: Gilgameš, Enkidu und die Unterwelt politisch gesehen,” BiOr 64 (2007), pp. 6-31: 26-29.

${ }^{52}$ See W. FARBER, "Lilû, Lilītu, Ardat-lilî," Reallexikon der Assyriologie und Vorderasiatischen Altertumskunde vol. 7, 1./2. fasc, (Berlin - New York 1987), pp. 23-24. Lilìtu and Ardat-Lilî can be compared to the concept of the incubus; both appear in later tradition as Lilith in Aramaic and Hebrew folk tales or as Jinni in Arabic folk lore; see F. A. M. WigGERMANN, "Lamaštu, Daughter of Anu. A Profile," in Stol, Birth in Babylonia and the Bible, pp. 217-252: 227- 230; M. HuTTER, "Lilith,"'in K. van der Toorn, B. Becking \& P. W. van der Horst, Dictionary of Deities and Demons in the Bible (Leiden - New York - Köln 1995), cols. 973-976; R. C. Thompson, Semitic Magic. Its Origins and Development (London 1908), pp. 65-72.

${ }^{53}$ The text, a list of simple drugs, is published in cuneiform autograph as BAM IV 380. The line in question is $B A M$ IV 380 rev. 29, duplicate is BAM IV 381 iii:22: Ú NUMUN GIš.HA.LU.ÚB

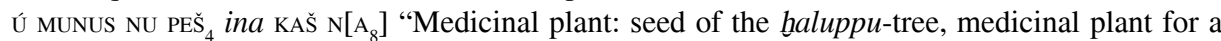


understand the rationale behind this recommendation as an allusion to the scene of the barren demon that is living in the trunk of Inanna's balub-tree.

The haluppu-tree is not the only tree that was related to Inanna. There are several other Sumerian compositions that mention the Euphrates poplar whose planting and growth were subject to the goddess' acts. ${ }^{54}$ The mention of the Euphrates poplar in the tale of Etana might have recreated a certain sexual atmosphere of the encounter between a man and a woman as well, since it is in the shadow of this tree that the gardener Šukaletuda rapes the young goddess Inanna as we are told in the Sumerian story of Inanna and Škaletuda. ${ }^{55}$ Another attestation comes from one of the Sumerian love songs where the Euphrates poplar is mentioned as a meeting place of the divine couple Dumuzi and Inanna.

According to the different compositions of Ancient Mesopotamian literature, it appears that not only each element isolated but also the connection of the motif of the eagle and the serpent intertwined with the image of the tree evoked associations of the topic of fertility, life and gestation. If we acknowledge that this imagery migrated to the world of ancient Israel, the relationship in Proverbs 30:18 between the eagle, the serpent, the boat, and a man and a woman becomes plausible in respect of contents, too. In the interpretation of the Biblical verses, we could thus distinguish between the formal tie using the Hebrew term dere $\underline{k}$ as stylistic feature of the four similes and the imagery of procreation as their associative bond. The last line in Proverbs 30:19 would then accordingly transfer the act of procreation from the mythological or symbolic realm into the human world by addressing directly a man and a woman.

\section{TOWARD A POSSIBLE UNDERSTANDING AND SETTING OF THE PROVERB}

In his article "The Riddle in the Bible," H. Torczyner (N. H. Tur-Sinai) put forward that numerical sayings such as Proverbs 30:18-19 were originally derived from riddles containing only the solution to the riddle author's ques-

woman who does not get pregnant, to drink with beer." The critical edition and study of this text genre is forthcoming by the author.

${ }^{54}$ See for textual references K. VoLK, Inanna and Šukaletuda. Zur historisch-politischen Deutung eines sumerischen Literaturwerkes (Wiesbaden 1995), p. 182.

${ }_{55}$ The poplar is referred to in lines 109, 157, 279 of the composition for which see VoLK, Inanna and Škaletuda (for line 109 see p. 128).

${ }^{56}$ The song is titled Oh that I might know the way to my beloved and is published by Y. SEFATI, Love Songs in Sumerian Literature. Critical Edition of the Dumuzi-Inanna Songs (Ramat Gan 1998), pp. 236-240 (for the commentary to line 24, see p. 244). 
tion ${ }^{57}$ He even proposed what might have been the question to which the lines of our proverb give the solution, namely "What goes and yet leaves no trace? What are the three or four things which go and which yet leave no trace?" 58 Some seventy years later, the hypothesis that many sayings in the book of Proverbs have undergone a transformation from riddles into the genre of proverbs has been challenged by Dan Pagis in his thoughtful study on literary riddles. ${ }^{59}$ In his contribution he took precisely Proverbs 30:18-19, as an example of a proverb misinterpreted as an original riddle. His critics should be quoted in full: "The biblical texts as it is presented hardly support such a view [i.e. proverb in response to a riddle], for the riddle's solution cannot be given 'in a few examples' but only in one specific answer [...] Yet the question, 'What moves, yet leaves no tracks' provides no hints at all, and endless answers are possible; some of them even appear in the Bible itself -wind, shadow, smoke, human life- quite apart from the vulture's flight, snake, ship, and man. Other scholars have held that these verses contained not a continuous answer to an absent riddle, but a riddle along with its solution - that is: 'There are three things which are too wonderful for me, four which I know not' is the riddle, while the continuation 'vulture, etc.' is the solution. But this cannot be true, either, for the same reason: the first verse does not provide a challenge (such as: 'Tell me, what four things do I know not') because it contains no hint of a solution; however wise a man may be, there will be more than four things he does not know. Three and four here are, in fact, a rhetorical expression meant to arouse the listener's attention to the direct continuation of the gnomic saying, without any genre transformation." ${ }^{60}$

Pagis did not have any access to the Ancient Mesopotamian literature discussed above, of which parts are published in form of autographs only. If the

${ }^{57}$ HUCA 1 (1924), pp. 125-149; see also his contribution "Hidah", in Entsyklopedia Mikrait, vol. 3 (Jerusalem 1958) (non vidi). For a discussion of the Hebrew term see H. P. MüLLER, "Der Begriff 'Rätsel' im Alten Testament," VT 20 (1970), pp. 465-489; on numerical sayings see the study of W. M. W. Rотн, Numerical Sayings in the Old Testament (Leiden 1965). Cf. B. Gemser, Sprüche Salomons (Tübingen 1963), p. 105, who speculates about the magical origin of enumerations and the riddle as origin of numerical proverbs. In his commentary Sprüche Salomons (Proverbia) (Neukirchen 1984), p. xvii, O. Plöger agrees with B. Gemser that numerical sayings had originated from riddles. A. Wünsche, on the other hand, favoured a rather didactic motive of such proverbs, see his "Die Zahlensprüche in Talmud und Midrasch," ZDMG 65 (1911), pp. 57-100: 57-61.

${ }^{58}$ HUCA 1 (1924), p. 136.

59 "Toward a Theory of the Literary Riddle," in G. Hasan-Rokem \& D. Shulman (eds.), Untying the Knot: On Riddles and Other Enigmatic Modes (New York 1996) p. 81-108.

60 "Toward a Theory of the Literary Riddle," pp. 102 and 103. 
interpretation of Proverbs 30:18-19 in the light of cuneiform literature proposed here were correct, we could identify one common denominator and, accordingly, only one possible solution to the four things, namely procreation. Our proverb could then be identified as a transformed or literary riddle and would fit well into the category of riddles that include a hint often expressed as a metaphor on how to solve other sections of the same riddle. ${ }^{61}$ The reference to the way of a man to / with a maid in Proverbs 30:19 would stand for the clue to understand the similes of eagle, serpent and boat.

Since riddles are found in virtually every human culture, many disciplines and scholars have investigated the origin, meaning, and function of this genre of discourse from their respective cultural perspectives. Folklorists distinguish between six different occasions in which the performance of riddles can occur. In his study on the appearance of riddles in various cultures, T. A. Burns lists the following settings which seem to be universal: (1) riddles can be a component in rituals, namely those of initiation and death; (2) riddling can be used on the occasion of courting; (3) riddles are an integral element of the educational encounter between teacher and student; (4) riddles form part of greeting formulas; (5) riddles appear in narratives and songs; and (6) riddling for leisure. ${ }^{6}$

According to the classification of Burns, Proverbs 30:18-19 would probably fit best into the scenery of courting. Support for this assumption is provided by other studies focusing on the setting and function of riddles especially in Biblical and Rabbinic texts. Worthwhile mentioning is the study of D. Stein on King Solomon and the Queen of Sheba. Although focusing on later Hebrew literature, she concludes that Biblical riddles also occur in situations of conflict in which tensions arise. ${ }^{63}$ She then distinguishes between intercultural tensions and erotic tensions, the latter providing a possible background for the interpretation of Proverbs 30 18:19. ${ }^{64}$ Stein goes even further in assuming that the association of the riddle within a wedding context "intensifies its erotic aspect." ${ }^{65}$ Solomon and the Queen of Sheba are not the only example for the feature of sexual ten-

${ }^{61}$ See PAGIS, "Toward a Theory of the Literary Riddle," pp. 89-90.

${ }^{62}$ See T. A. Burns, "Riddling: Occasion to Act," Journal of American Folklore 89 (1976), pp. 139-165.

${ }^{63}$ D. STEIn, "A King, a Queen, and the Riddle Between: Riddles and Interpretation in a Late Midrashic Text," in Hasan-RoKem \& Shulman (eds.), Untying the Knot, pp. 125-147.

${ }^{64}$ STEIN, "A King, a Queen, and the Riddle Between," p. 128. For the performance of riddles in order to solve intercultural tensions, see also C. R. FonTAine, "Proverb Performance in the Hebrew Bible," JSOT 32 (1985), pp. 87-103.

${ }^{65}$ STEIN, “A King, a Queen, and the Riddle Between,” p. 129. 
sion; a rather obvious case relating a wedding ceremony is without doubt the well-known story of Samson and his riddle, as it is told in Judges 14:14-18.

In view of the universal and well-attested setting of riddles in erotic situations on the one hand and considering, on the other hand, our analysis of Proverbs 30:18-19 as a literary riddle, we would then propose that the couplets could have originally served to entertain bride and groom and / or their wedding guests.

Recibido: $25 / 08 / 2008$

Aceptado: 03/07/2009 (versión final)

${ }^{66}$ See for the function of riddles during wedding ceremonies D. Noy, "Hiddot bi-se'udat hatunah," Mahanayim 83 (1963), pp. 64-71 (non vidi); cf. also E. Slotkin, "Response to Professors Fontaine and Camp," in S. NIDITCH (ed.), Text and Tradition. The Hebrew Bible and Folklore (Atlanta, GA), pp. 153-162. For Samson's riddle see e.g. the contribution of P. NeL, "The Riddle of Samson," Biblica 66 (1985), pp. 534-545, and C. V. Camp \& C. R. Fontaine, "The Words of the Wise and their Riddles," in NIDITCH (ed.), Text and Tradition, pp. 127-151 with previous literature. 
